\title{
EFEK SELF EFFICACY TRAINING TERHADAP SELF EFFICACY DAN KEPATUHAN DIET DIABETESI
}

\author{
Ainul Yaqin ${ }^{1)}$, Safitri Niken"), Edi Dharmana ${ }^{3)}$ \\ Mahasiswa Magister Keperawatan Fakultas Kedokteran, Universitas Diponegoro \\ email: ainulyaqin63@gmail.com \\ Staf Pengajar Departemen Keperawatan Fakultas Kedokteran, Universitas Diponegoro \\ Staf Pengajar Fakultas Kedokteran, Universitas Diponegoro
}

\begin{abstract}
Abstrak
Pasien diabetes mellitus (DM) seringkali tidak patuh terhadap pola diet yang dianjurkan. Banyak pasien DM yang mengalami berat badan berlebih atau kurus. Ketidakpatuhan diet menyebabkan rendahnya kontrol glikemik, dan meningkatkan komplikasi, disability and mortality. Kepatuhan dipengaruhi oleh keyakinan diri/self efficacy (SE), di sisi lain program peningkatan SE terkait dietDM belum banyak diteliti. Self efficacy training (SET)mampu meningkatkan SEsehingga kepatuhan diet meningkat. Tujuan penelitian untuk menganalisis efek SET terhadap SE dan kepatuhan diet diabetesi. Metode menggunakan quasy experiment dengan rancangan post test nonequivalent control group. Sampel kelompok intervensi dan kontrol masing-masing 48 dan 51 orang. Intervensi dilakukan sebanyak 6 sesi selama 12 hari. Hasil menunjukkan mayoritas responden adalah perempuan dengan usia 58-67 tahun. SE diukur dengan kuisioner DIET-SE dan kepatuhan dengan PDAQ Selisih nilai mean SE kelompok intervensi dan kontrol setelah perlakuan adalah 4,27 dengan $p=0,000$ dan selisih mean kepatuhan diet kelompok intervensi dan kontrol adalah 5,94 dengan $p=0,000$. Hasil uji multivariat dengan MANOVA didapatkan ada efek SETpada kedua variabel dependen yang sangat bermakna $(p=0,000)$, namun jika dilihat dari hasil selisih mean dengan kelompok kontrol, variabel kepatuhan memiliki peningkatan nilai mean yang lebih besar dibandingkan variabel SE. Kesimpulan penelitian SET dapat meningkatkan kepatuhan diet pasien DM melalui peningkatan SE.
\end{abstract}

Kata kunci: sef efficacy training; self efficacy; kepatuhan

\begin{abstract}
Diabetic Mellitus (DM) patients are often not adherent to the recommended dietary patterns. Many DM patients are overweight or underweight. Dietary adherence leads to lower glycemic control, and increases complications, disability and mortality. Adherence is influenced by self-efficacy (SE), on the other hand SE improvement programs related to DM diet has not been much studied. Self efficacy training (SET) is able to improve SE so that diet compliance increases. The objective of the study was to analyze the effects of SET on SE and adherence to the diabetic diet. The method used quasy experiment with post tes nonequivalent control group design. The sample of the intervention and control groups were each 481 person. Intervention conducted as much as 6 sessions for 12 days. Results showed the majority of respondents were women aged 58-67 years. SE is measured by a DIET-SE questionnaire and compliance with PDAQ. The mean difference of SE values of the intervention and control groups after treatment was 4.27 with $p=0,000$ and the mean difference of dietary intervention group and intervention was $5.94 p=0,000$. The result of multivariate test with MANOVA showed that there was a SET effect on both highly significant dependent variables $(p=$ 0.000_, but if seen from the result of mean difference with the control group, the compliance variable had higher mean value than the SE variable. Improving DM patient's compliance through SE enhancement.
\end{abstract}

Keywords: self efficacy training; self efficacy; obedience 


\section{PENDAHULUAN}

Sebagian besar pasien diabetes mellitus (DM) gagal dan tidak patuh pada program diet yang dianjurkan (International Diabetes Federation (IDF), 2015). Hasil penelitian Bakr (Bakr, 2015) menyebutkan sebanyak 3,2\% wanita tidak pernah makan sayur, 56\% dari pria dan 50\% dari wanita senang makan daging merah (dark meat), 28\% dari laki-laki dan 28,5\% dari wanita jarang makan buah dan $50 \%$ dari laki-laki dan $42,5 \%$ dari wanita masih suka makanan manis. Adebisi (Adebisi, 2013) menyebutkan bahwa $43,4 \%$ dari responden wanita dan $13,5 \%$ dari laki-laki memiliki tubuh yang obesitas. Fakta lain menyebutkan banyak pasien DM hanya mengurangi nasi dan makanan manis tanpa memperhatikan keteraturan jadwal makan, pemilihan jenis makanan, dan total kalori dalam satu hari sehingga kadar guladarah tinggi ataubahkan rendah (Al Tera, 2011).

Ketidakpatuhan diet menyebabkan buruknya kontrol gula darah(hiperglikemia dan hipoglikemia. Kontrol gula darah yang buruk secara langsung menyebabkan ketidakstabilan metabolisme dan hemodinamik tubuh (Dyson et al., 2011; Intercollegiate \& Network, 2013; (IDF), 2015). Lebih lanjut, jika kadar gula darah tidak terkontrol maka komplikasi jangka panjang yang lebih berbahaya seperti penyakit jantung dan luka diabetik, retinopati (rabun), neuropati dan nepropati (gagal ginjal) akan meningkat. Semua komplikasi tersebut membuat pasien tidak produktif, menurunkan kualitas hidupnya, menjadi beban keluarga dan negara secara ekonomi (Papazafiropoulou et al., 2015; Safita et al., 2016; Wright, 2013).

World Health Organization (WHO) melaporkan ada 4 faktor yang mempengaruhi kepatuhan, yaitupengobatan dan karakteristik penyakit, intra-personal (faktor internal), interpersonal (faktor eksternal) dan lingkungan. (World Health Organization, 2003) Pengobatan dan karakteristik penyakit meliputi kompleksitas perawatan, keseriusan penyakit, dandelivery of care (layanan perawatan). Viswanathan, dkk melaporkan pasien yang diresepkan obat tunggal memiliki tingkat kepatuhan jangka pendek dan jangka panjang yang lebih baik dibandingkan dengan peresepan lebih dari dua atau lebih (Viswanathan et al.,
2012). Keseriusan penyakit memiliki hubungan negatif dengan kepatuhan. Inbaraj dkk (2016) menyebutkan Semakin lama pasien menderita DM, semakin kecil kemungkinan patuh terhadap pengobatan(Inbaraj, Georg, Kham, \& Norman, 2016). Fasilitas layanan kesehatan merupakan salah satu kunci pasien DM dapat menjaga kepatuhan perawatan. PasienDM yang menerima konseling tentang diet memiliki kepatuhan yang lebih baik daripada pasien yang tidak menerima konseling. Akses fasilitas kesehatan yang terjangkau akan memudahlan pasien DM untuk terus menjaga kesehatannya secara konsisten (WHO, 2003).

Faktor inter-personal pasien dibagi menjadi 6, yaitu usia, jenis kelamin, harga diri (self esteem), keyakinan diri (self efficacy), stres dan depresi. Dibandingkan dengan pasien yang lebih muda, pasien dengan umur lebih dari 25 tahun melakukan olahraga lebih sedikit dan menghabiskan sedikit waktu (pengeluaran kalori lebih sedikit) dalam aktivitas fisik (Bernardini et al., 2004). Wanita cenderung memiliki kepatuhan yang lebih tinggi daripada laki-laki (Hendrychova, Vytrisalova, Vlcek, Smahelova, \& Kubena, 2013). Penelitian membuktikan bahwa self esteem berhubungan dengan latihan fisik dan indek massa tubuh (IMT) pada pasien DM (Kaminsky \& Dewey, 2014). Diketahui bahwa tingkat self efficacy pasien DM menjadi prediktor terkuat pasien DM mematuhi regimen penatalaksanaan (Bandura, 1977). Pasien dengan stres dan depresi lebih mungkin mengalami komplikasi, dan memiliki kontrol glikemik yang lebih buruk, serta kurang patuh terhadap perilaku perawatan diri dibandingkan pasien yang tidak depresi (Pant, Ojha, Chapagai, Tulachan, \& Dhungana, 2016).

Faktor inter-personal dan lingkungan meliputi dukungan sosial. Pasien yang menerima dukungan sosial yang baik memiliki kecenderungan untuk mematuhi anjuran diet, obat, latihan fisik dan pengontrolan gula darah secara periodik (Rosland et al., 2014).Perubahan lingkungan seperti sistem komunikasi, sosial, ekonomi, budaya sangat berhubungan erat dengan kepatuhan seseorang terhadap regimen perawatan (Parajuli, Saleh, Thapa, \& Ali, 2014).

Diperlukan usaha, baik dari pasien dan tenaga kesehatan sehingga tercapai perubahan 
perilaku diet pada pasien DM. Salah satu faktor penentu dalam mencapai perubahan perilaku diet adalah self-efficacy (keyakinan diri). Wu dkk (Wu et al., 2007)menyebutkandalam penelitiannya $78 \%$ pasien DM memiliki self efficacy yang rendah. Lebih lanjut Herbozo ddk (Herbozo, Flynn, \& Stevens, 2015) dan Gatt dkk (Gatt \& Sammut, 2008) menyebutkan bahwa responden smayoritas memiliki self efficacy yang rendah. Self efficacy yang rendah berkorelasi dengan buruknya perawatan diri (self management) pasien DMdalam mematuhi diet, olahraga, kontrol gula darah, dan pengambilan keputusan(Astuti, 2014).

Pemerintah berusaha untuk melakukan pencegahan komplikasi dan rehabilitasi penyakit DM dilakukan melalui program kegiatan Posbindu Penyakit Tidak Menular (PTM) dalam bentuk monitoring, perawatan kaki DM, diet sehat kalori seimbang, dan senam kaki (Kementerian Kesehatan RI, 2015). Hasil survey Badan Penelitian dan Pengembangan Kesehatan (litbang) tahun 2015 menyebutkan bahwa pada kelompok dengan penyakit DM, masih banyak pasien yang mengkonsumsi lemak lebih dari 67 gram perhari (> 67 gr/hari) sebanyak $26,61 \%$, konsumsi gula lebih dari 50 gram perhari (>50 gr/hari) sebanyak $5,7 \%$. Hasil tersebut membuktikan usaha pemerintah masih belum optimal dan cenderung kurang efektif.

Peningkatan self efficacy dengan self efficacy training terbukti efektif dalam meningkatkan kepatuhan pada berbagai subjek penelitian sebelumnya. Tsay (Tsay, 2003) melaporkan bahwa self efficacy training dapat meningkatkan kepatuhan pembatasan cairan pada pasien gagal ginjal. Ariyanti(Ariyanti, 2016) juga melaporkan SET memiliki pengaruh yang sangat bermana terhadap self efficacy dan kepatuhan pada pasien gagal ginjal yang menjalani hemodialisa. Program peningkatan self efficacy dengan self efficacy training

1. Karakteristik Responden

Tabel 1. Karakteristik Responden

\begin{tabular}{|c|c|c|c|c|}
\hline \multirow[b]{2}{*}{ No. } & \multirow[b]{2}{*}{ Karakteristik } & \multicolumn{2}{|c|}{ Frekuensi (\%) } & \multirow[b]{2}{*}{$\begin{array}{l}\text { Nilai } \mathrm{p} \\
\text { Value }\end{array}$} \\
\hline & & $\begin{array}{c}\text { Perlakuan } \\
(\mathrm{n}=48)\end{array}$ & $\begin{array}{l}\text { Kontrol } \\
(\mathrm{n}=51)\end{array}$ & \\
\hline \multirow[t]{4}{*}{1.} & Usia & & & \\
\hline & Dewasa akhir (38-47 tahun) & $8(16,7 \%)$ & $5(9,8 \%)$ & \\
\hline & Lansia awal Pertengahan ( $48-57$ tahun) & $12(25 \%)$ & $18(35,3 \%)$ & 0.122 \\
\hline & Lansia Pertengahan (58-67 tahun) & $17(35,4 \%)$ & $19(37,2 \%)$ & \\
\hline
\end{tabular}

berhubungan erat dengan manajemen perawatan diri dan kontrol glikemik tubuh (AlKhawaldeh, Al-Hassan, \& Froelicher, 2012).Tujuan penelitian ini adalah menganalisis efek dari pemberian SET terhadap self efficacy dan kepatuhan diet diabetesi.

\section{METODE PENELITIAN}

Penelitian ini menggunakan kuantitatif quasy experimental dengan post test desain, Pengambilan sample menggunakan simple random samplingdan didapatkan 48 responden pada kelompok intervensi dan 51 responden pada kelompok kontrol. Kriteria inklusi responden yaitutidak mengalami gangguan psikologis maupun kognitif dan mampu untuk membaca dan menulis. Syarat tersebut menjadi penting karena proses penelitian sangat berhubungan dengan usaha untuk meningkatkan kemampuan kognitif responden dan terkait dengan penilaian kedua variabel. Kriteria eksklusi yaitu responden yang tidak mengikuti proses penelitian secara lengkap.

Kelompok intervensi diberikan perlakuan sebanyak 6 kali selama 12 hari dengan durasi 60-100 menit setiap kali pertemuan. Jarak penelitian satu dengan selanjutnya adalah 1 hari sedangkan kelompok kontrol mengikuti kegiatan seperti biasa di paguyuban setiap minggu.Self efficacy diukur dengan menggunakan kuisioner The DietSelf Efficacy Scale(DIET-SE) dan kepatuhan diet diukur dengan kuisioner Percieved Dietary Adherence Questioner (PDAQ). DIET-SE terdiri dari 10 pertanyaan sedangkan PDAQ 8 pertanyaan. Data kemudian dianalisis menggunakan uji statistik MANOVA. Penelitian ini dilakukan di salah satu paguyuban diabetes di Magelang.

\section{HASIL DAN PEMBAHASAN}




\begin{tabular}{|c|c|c|c|c|}
\hline & Lansia akhir (68 - 77 tahun) & $11(22,9 \%)$ & $9(17,7 \%)$ & \\
\hline 2. & $\begin{array}{l}\text { Pendidikan terakhir } \\
\text { Tidak sekolah } \\
\text { SD } \\
\text { SMP } \\
\text { SMA } \\
\text { Perguruan tinggi }\end{array}$ & $\begin{array}{c}2(4,2 \%) \\
14(29,1 \%) \\
13(27,1 \%) \\
12(25 \%) \\
7(14,6 \%)\end{array}$ & $\begin{array}{c}0(0 \%) \\
15(29,4 \%) \\
12(19,6 \%) \\
22(43,1 \%) \\
2(7,9 \%)\end{array}$ & 0.172 \\
\hline 3 & $\begin{array}{l}\text { Jenis kelamin } \\
\text { Laki-laki } \\
\text { Perempuan }\end{array}$ & $\begin{array}{l}12(25 \%) \\
36(75 \%)\end{array}$ & $\begin{array}{l}18(35,3 \%) \\
33(64,7 \%)\end{array}$ & 0.557 \\
\hline 4. & $\begin{array}{l}\text { Penghasilan } \\
\text { Tidak ada } \\
<1.500 .000 / \text { bulan } \\
\geq 1.500 .000 / \text { bulan }\end{array}$ & $\begin{array}{c}4(8,4 \%) \\
16(33,3 \%) \\
28(58,3 \%)\end{array}$ & $\begin{array}{c}6(8,4 \%) \\
24(33,3 \%) \\
21(58,3 \%)\end{array}$ & 0.692 \\
\hline 5. & $\begin{array}{l}\text { Pekerjaan } \\
\text { Tidak bekerja } \\
\text { IRT } \\
\text { Petani } \\
\text { Buruh } \\
\text { Pedagang } \\
\text { Pegawai swasta } \\
\text { Pegawai negeri } \\
\text { Pensiunan } \\
\text { Lain-lain }\end{array}$ & $\begin{array}{c}3(6,3 \%) \\
17(35,4 \%) \\
0(0 \%) \\
0(0 \%) \\
16(33,3 \%) \\
0(0 \%) \\
0(0 \%) \\
12(25 \%)\end{array}$ & $\begin{array}{c}6(11,7 \%) \\
23(45,1 \%) \\
5(9,8 \%) \\
0(0 \%) \\
14(27,5 \%) \\
0(0 \%) \\
0(0 \%) \\
3(5,9 \%\end{array}$ & 0,027 \\
\hline
\end{tabular}

Diketahui bahwa persentase tertinggi umur responden pada kelompok intervensi dan kontrol berada pada kategori umur antara 58-67 tahun sebanyak $35,4 \%$ (17 orang) dan $37,2 \%$ (19 orang). Kelompok intervensi paling banyak berpensisikan SD sebanyak 29,1\% (14 orang) dan sebanyak 43,1\% (22 orang) pada kelompok kontrol adalah SMA. Jenis kelamin paling banyak kelompok intervensi dan kontrol adalah perempuan, yaitu 36 orang (75\%) dan 33orang $(64,7 \%)$. Mayoritas responden pada kelompok intervensi memiliki penghasilan $\geq$ $1.500 .00 /$ bulan sebanyak $58,3 \%$ (28 orang) sedangkan kelompok kontrol persentase tertinggi adalah responden yang berpenghasilan $<1.500 .000 /$ bulan sebanyak 33,3\% (24 orang). Pekerjaan kelompok intervensi dengan presentase tertinggi 35,4\% (17 orang) adalah ibu rumah tangga (IRT)dan sama halnya pada kelompok kontrol, mayoritas pekerjaan responden adalah bekerja IRT sebanyak 45,1\% (23 orang). Semua karakterisitik responden memiliki nilai $\mathrm{p}$ value lebih dari 0.05 kecuali pada pekerjaan responden, namun masih dapat disimpulkan karakteristik responden homogen.

2. Self Efficacy responden

Tabel 2. Self EfficacyResponden

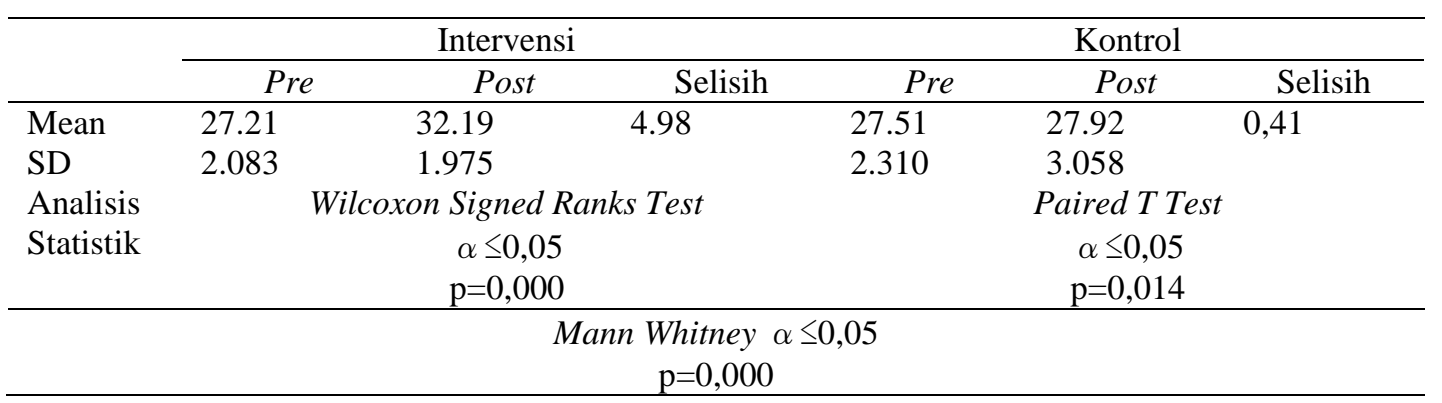


Tabel 2 menunjukkan bahwa ada perbedaan rata-rata nilai meanself efficacy pada kelompok kontrol dan perlakuan. Self efficacy pada kelompok intervensi memiliki nilai mean lebih tinggi daripada kelompok kontrol. Hasil uji Wilcoxon Signed Ranks Test menunjukkan bahwa terdapat peningkatan nilai self efficacy yang bermakna pada kelompok perlakuan yang mendapatkan pelatihan self efficacy trainingdengan metode peer support group. Hal ini dibuktikan dengan nilai $\mathrm{p}=0,000$ atau $\mathrm{p}<0,05$.

3. Kepatuhan Diet Responden

Tabel 3. Kepatuhan Diet Responden

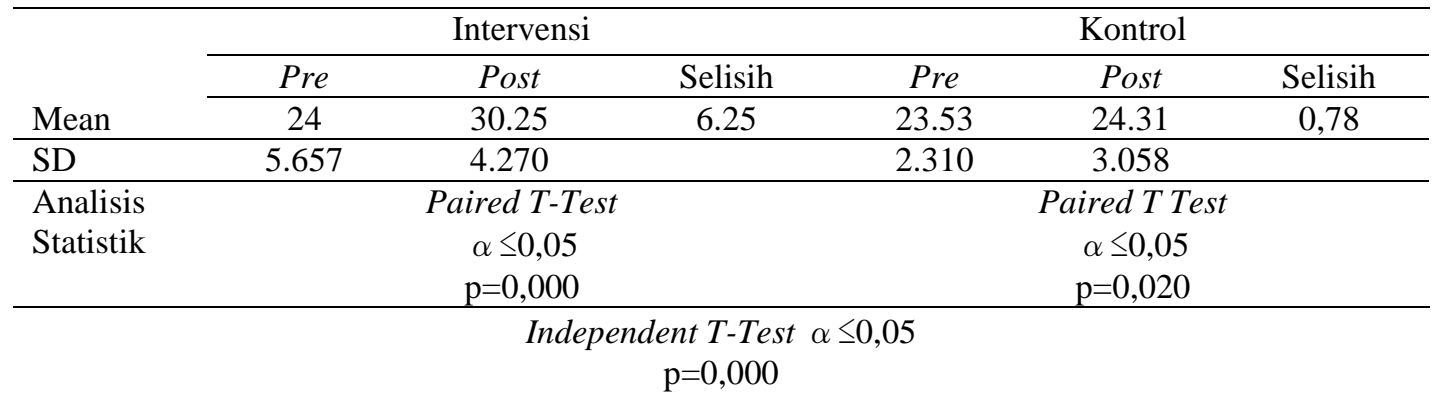

Tabel 3 menunjukkan bahwa terdapat perbedaan rata-rata nilai meankepatuhan diet pada kelompok kontrol dan perlakuan. Kepatuhan diet pada kelompok intervensi memiliki nilai mean yang lebih tinggi daripada kelompok kontrol. Hasil uji Paired T-Test Test menunjukkan bahwa terdapat peningkatan nilai kepatuhanyang bermakna pada kelompok intervensi yang mendapatkan pelatihan self efficacy trainingdengan metode peer support group. Hal ini dapat dilihat berdasarkan nilai $\mathrm{p}=0,000$ atau $\mathrm{p}<0,05$.

4. Efek Self Efficacy Training terhadap Self Efficacy dan Kepatuhan

Tabel 4. Analisis Efek Self Efficacy Training terhadap Self Efficacy dan Kepatuhan

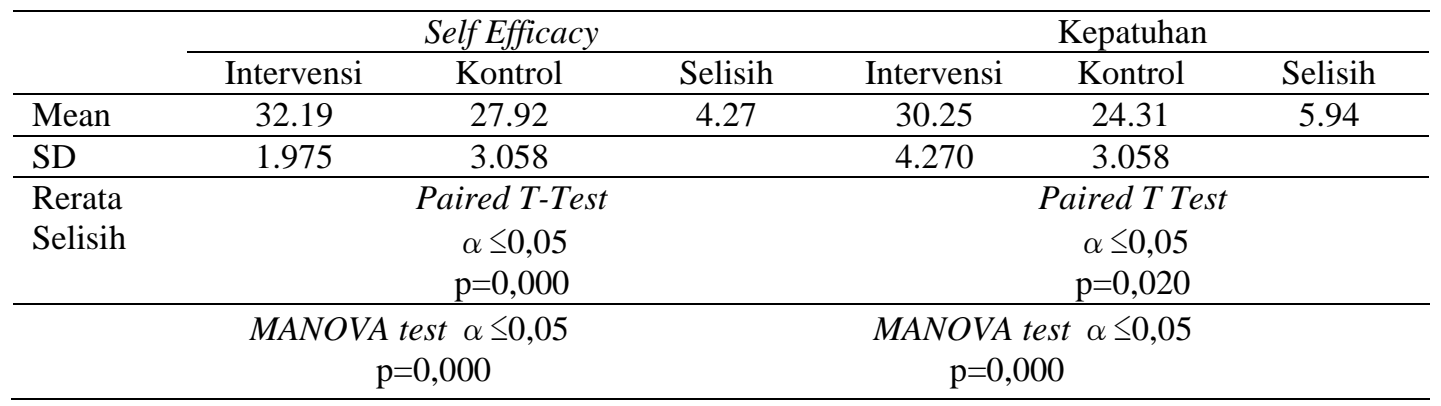

Tabel 4 menunjukkan bahwa variabel self efficacy dan kepatuhan diet setelah perlakuan mengalami peningkatan rerata nilai mean, baik pada kelompok intervensi maupun kontrol. Hasil uji MANOVA menunjukkan nilai asymp sig 0,000 yang berarti ada yang sangat bermakna self efficacy training dengan metode peer support group pada self efficacy dan kepatuhan diet, walaupun jika dibandingkan dengan selisih nilai rerata mean kelompok intervensi dan kelompok kontrol, variabel kepatuhan diet memiliki selisih yang lebih besar daripada slisih nilai mean pada self efficacy.

Hasil penelitian menunjukkan bahwa ada perbedaan self efficacy, dan kepatuhan setelah setelah dilakukan selfefficacy training dengan metode peer support groupdalam 6 kali pertemuan selama 12 hari (post test) pada kelompok intervensi dan kontrol. Peningkatan self efficacy, dan kepatuhan pada kelompok intervensi lebih signifikan jika dibandingkan dengan kelompok kontrol. Dilihat dari selisih mean sebelum dan sesudah perlakuan, variabel 
kepatuhan memiliki selisih mean paling tinggi dibandingkan dengan selisih mean variabel selfefficacy. Hasil uji statistik dengan MANOVA nilai $\mathrm{p}=0,000$, baik pada kelompok intervensi maupun kontrol. Kesimpulan yang dapat diambil adalah self efficacy training sama-sama memiliki pengaruh yang kuat pada kedua variabel dependent walaupun jika dibandingkan dengan nilai mean, self efficacy training lebih signifikanmempengaruhi kepatuhan diet respondendibandingkan dengan variabel self efficacy.

Hasil penelitian sebelumnya yang dilakukan oleh $\mathrm{Ha}$ (Ha, Hu, Petrini, \& McCoy, 2014) menyebutkan bahwa educational self efficacy interventiondapatmeningkatkan self efficacy, yang dibuktikan dengan peningkatan diabetesself management pada pasien DM tipe 2. Hasil penelitian Wichit(Wichit, Mnatzaganian, Courtney, Schulz, \& Johnson, 2017) menyebutkan terdapat pengaruh yang signifikan terhadap peningkatan self efficacy pada responden yang mendapatkan program peningkatan self efficacy sebanyak tiga kali sesi edukasi (pre test, minggu ke 5 dan minggu ke sembilan) selama 14 minggu.

Hasil penilaian variabel kepatuhan penelitian saat ini juga sejalan dengan beberapa penelitian yang pernah dilakukan sebelumnya. Hasil penelitian Yi, et al menunjukkan terdapat perbedaan mean kepatuhan diet (general diet dan special diet) setelah dilakukan perlakuan pada kelompok intervensi dan kontrol masingmasing sebesar 0,95 dan 0,86 dengan $\mathrm{p}=0,01$. Nilai mean kepatuhan pada kelompok intervensi setelah perlakukan lebih tinggi dibandingkan dengan nilai mean kepatuhan kelompok kontrol. Nilai mean kepatuhan pada kelompok intervensi setelah perlakukan juga mengalami peningkatan sebesar 0,84 pada kuisioner general diet dan 0,77 pada kuisioner special diet (Yin et al., 2015). Lebih lanjut, penelitian Swoboda menyimpulkan terdapat perbedaan mean kepatuhandiet setelah dilakukan perlakukan pada kelompok intervensi dan kontrol sebesar 0,4 menggunakan kuisioner Healthy Eating Index 2010 Score. Nilai tengah kepatuhan pada kelompok intervensi lebih tinggi dibandigkan kelompok kontrol. Kelompok intervensi juga mengalami peningkatan nilai rata-rata mean kepatuhan sebesar 3,20 (Swoboda, Miller, \& Wills, 2017).
Peneliti di dalam hipotesanya menyebutkan bahwa pemberian pelatihan self efficacy training dengan metode peer support group dapat memberi efek terhadap self efficacy dan kepatuhan. Hipotesa yang diajukan oleh peneliti merupakan kesimpulan yang diambil peneliti berdasarkan teori-teori tentang self efficacy, pengaruh, kemanfaatan dan keberhasilan self efficacy training dalam mengubah perilaku (change behavior) dari beberapa hasil penelitian sebelumnya baik pada responden dengan penyakit DM maupun penyakit yang lain.

Hasil penelitian saat ini sesuai dengan hipotesa penelitian yang diajukan, yaitu self efficacy training dengan metode peer support group berpengaruh terhadap peningkatan self efficacy dan kepatuhan diet diabetesi di Paguyuban Diabetes RSJ. Prof. Dr. Soerojo Magelang. Self efficacy training dengan metode peer support group mampu mempengaruhi self efficacy dan kepatuhan karena pelatihan yang diberikan oleh peneliti tidak bersifat konvensional (ceramah) tetapi lebih bersifat patient center learning, dimana peneliti membuat setiap pertemuan menjadi lebih interaktif dan membuat antar anggota kelompok dapat saling memberikan pendapatnya. Lebih lanjut, adanya pemberian kemampuan kepada pasien terkait dalam menghitung jumlah kalori dan menakan menu makanan serta motivasi (verbal persuation) dari survivor DM (PANDU) memberikan pengaruh yang sangat signifikan dalam memotivasi responden untuk patuh terhadap pola diet yang dianjurkan.

Self efficacy training merupakan kegiatan pelatihan yang digunakan untuk meningkatkan keyakinan diri seseorang yang diharapkan dapat mempengaruhi perubahan perilaku ke arah yang lebih baik. Self efficacy training merupakan suatu kegiatan atau pelatihan yang dilakukan oleh seorang trainer (pelatih) kepada seseorang atau kelompok sehingga seseorang atau kelompok tersebut mampu memiliki keyakinan (belief) terhadap kemampuannya dalam mencapai suatu tujuan.(Combs \& Luthans, 2007)Peneliti berpendapat bahwa hasil penelitian saat ini yang menyebutkan bahwa terdapat efek yang signifikan self efficacy training terhadap self efficacy dan kepatuhan tidak terlepas dari komponen-komponen yang dipenuhi oleh peneliti, yaitu empat komponen yang mempengaruhi self efficacy(mastery 
experience, verbal persuation, role modelling dan physicological arousal) dan metode peer support yang digunakan.

Mastery Experience (penguasaan pengalaman) bertujuan memberikan pengalaman keberhasilan kepada individu Cara yang paling efektif dalam menciptakan keyakinan yang kuat adalah pengalaman (experience) pribadinya. Seseorang yang berpengalaman tentang sesuatu memiliki kepercayaan dan keyakinan diri untuk bertindak dan cenderung berpeluang untuk berhasil dalam tugasnya. Sebaliknya, kegagalan karena kurangnya pengalaman akan membuat keyakinan dirinya hilang (Bandura, 1977). Ketika individu mengalami pengalaman keberhasilan maka keyakinan dirinya (self efficacy) akan meningkat. Penelitian ini memberikan pengalaman kepada responden pada kelompok kontrol tentang cara mereka unuk menghitung kalori dan menakarnya dalam bentuk makanan. Setelah seseorang memiliki keyakinan (self efficacy), maka dia tahu apa yang diperlukan untuk mencapai keberhasilan melalui ketekunan dalam menghadapi kesulitan dan cepat kembali dari keterpurukan (tidak mudah menyerah).(DeVellis, 1983)

Role Modelling (teladan/panutan) adalah cara untuk meningkatkan self efficacy melalui pengalaman keberhasilan orang lain. Seseorang cenderung untuk mencari model atau teladan yang sama dengan dirinya. Keberhasilan orang lain dalam mecapai tujuannya yang memiliki kondisi yang sama dengan dirinya akan menjadi teladan. Melihat orang lain berhasil dengan upaya berkelanjutan menimbulkan keyakinan diri.Pengalaman keberhasilan orang lain dapat menjadikan motivasi bagi seseorang yang melihat untuk dapat meniru (duplicate). Aspek Role modelling dalam penelitian ini adalah dengan menciptakan proses kegiatan yang memungkinkan seseorang yang dianggap menjadi panutan oleh anggotanya dan telah bertahan dengan penyakitnya (survivor) untuk dapat memberikan pengalaman keberhasilan dalam program dietnya. Dampak dari pemodelan pada self-efficacy sangat dipengaruhi oleh persepsi kesamaan dengan model. Semakin besar kesamaan dengan model (teladan) maka semakin besar pula kemungkinan seseorang mencapai keberhasilan atau kegagalan.(Novack, 2013)'(Bandura, 1977)
Verbal persuation (persuasi verbal) adalah ajakan secara verbal untuk memperkuat self efficacy seseorang. Bandura berpendapat bahwa ketika ada seseorang yang memberikan dukungan dan keyakinan secara verbal untuk melakukan tugas kepada orang lain, maka orang yang didukung cenderung lebih percaya bahwa dirinya memiliki kemampuan untuk menyelesaikannya. Umpan balik konstruktif/sharing (Constructive feedback) dalam penelitian ini sangat penting untuk menjaga keyakinan diri (sense of efficacy) yang membantu menghilangkan keraguan dalam dirinya.(Bandura, 1977)

Physiological arousal (semangat fisiologis) mampu mempengaruhi kekuatan self efficaycy seseorang. Bandura membagi Physiological arousal menjadi dua, yaitu gairah fisik (physical arousal) dan gairah emosional (emotional arousal). Kekuatan, stamina seseorang menentukan kemampuannya dalam mencapai tujuan, misalnya orang dengan keluhan lelah (fatigue) cenderung malas dan tidak cukup energi untuk beraktifitas. Mood, cemas, takut, stess, dan depresi menjadi bagian yang membuat seseorang tidak memiliki kemampuan dan keyakinan yang tinggi.(DeVellis, 1983). Untuk menjaga menjaga semangat/gairah baik secara fisik dan psikis maka peneliti menggunakan metode peer support group yang mengedepankan responden sebagai sumber utama kelompok (patient centered learning) untuk mencari informasi dan pengalaman.

Peer support dalam self efficacy training adalah teman kelompok, motivator, pelatih, rekan, role model. Peer support atau yang dalam penelitian ini disebut dengan PANDU adalah seseorang yang telah mampu untuk mengelola dan merawat penyakit DM, patuh pada lima pilar prinsip pencegahan dan penatalaksanaan penyakit DM (survivor). Pendekatan edukasi/ pendidikan kesehatan saat ini semakin berkembang, baik secara teoritis (substansi) maupun teknis pembelajaran. Pendekatan edukasi dan pelatihan dengan metode peer (teman sebaya) dianggap sebagai metode yang efektif dalam menyalurkan sebuah informasi termasuk informasi kesehatan. Pendekatan edukasi yang digunakan peneliti dalam penelitian ini sejalan dengan paradigma pelayanan kesehatan saat ini, yaitu patient centered bukan lagi health workers centered 
dan paradigma from serving to partnering. Bertolak belakang dengan pembelajaran konvensional yang masih berpusat pada pemberi materi dan cenderung mengutamakan hapalan, dan mengutamakan hasil daripada proses, maka metode peer (teman sebaya) merupakan metode yang menekankan pada proses pembelajaran dan mengutamakan sharing knowledge (berbagi pengetahuan), sharing ideas (berbagi pendapat) dan sharing experience (berbagi pengalaman) dari teman sebaya sehingga proses pembelajaran menjadi lebih efektif, menyenangkan dan tidak membosankan. (Rubin, Bukowski \& Parker, 1998).

\section{KESIMPULAN DAN SARAN}

Berdasarkan hasil penelitian, dapat disimpulkan bahwa self efficacy memiliki peranan yang sangat penting dalam merubah perilaku kesehatan seseorang. Self efficacy erat hubungannya dengan kepatuhan, termasuk kepatuhan diet pada diabetesi. Semakin baik self efficacy yang dimiliki seseorang maka semakin baik juga perilaku kesehatannya. Tenaga kesehatan harus mempertimbangkan untuk memberikan latihan self-efficacy untuk meningkatkan kepercayaan diri pasien DM dalam mengendalikan pola makan yang sehat.Perawat memiliki peranan penting untuk mempengaruhi self-efficacy pasien DM dan dapat mendorong mereka untuk menerapkan strategi perawatan mandiri. Hasil penelitian diharapkan dapat bermanfaat bagi tenaga kesehatan profesional yang terlibat dalam praktik pendidikan kesehatan pada pasien diabetes khusunya pada aspek kepatuhan diet.

\section{REFERENSI}

Adebisi, T. T. (2013). Assessment of Nutritional Status of Diabetic Patients in Ogun State, Nigeria. American Journal Of Human Ecology, 3(April), 1-10.

Al-Khawaldeh, O. A., Al-Hassan, M. A., \& Froelicher, E. S. (2012). Self-efficacy, self-management, and glycemic control in adults with type 2 diabetes mellitus. Journal of Diabetes and Its Complications, 26(1), 10-16. https://doi.org/10.1016/j.jdiacomp.2011.1 1.002
Al Tera, B. H. (2011). Determinan Ketidakpatuhan Diet Penderita Diabtete Melitus Tipe 2. Skripsi. Diponegoro University.

Ariyanti, F. (2016). Pengaruh Self Efficacy Training dengan Metode Peer Mentoring terhadap Self efficacy daan Kepatuhan Pasien Gagal Ginjal Kronik yang Menjalani Hemodialisa. Universitas Airlangga.

Astuti, N. (2014). Efikasi Diri Dan Manajemen Diri Pada Pasien Diabetes Tipe 2. Universitas Sumatra Utara.

Bakr, E. H. (2015). Nutritional Assessment of Type II Diabetic Patients. Pakistan Journal of Nutition, 14(6), 308-315.

Bandura, A. (1977). Self Efficacy:Toward a unifying theory of behavioral change. Psychological Review, 84(2), 191-215. https://doi.org/10.1037/0033295X.84.2.191

Bernardini, A., Vanelli, M., Chiari, G., Iovane, B., Gelmetti, C., Vitale, R., \& Errico, M. (2004). Adherence to physical activity in young people with type 1 diabetes. Acta Biomed, 3(75), 153-7.

Combs, G. M., \& Luthans, F. (2007). Diversity training: Anasis of the impact of selfefficacy. Human Resource Development Quarterly, 18(1), 91-120. https://doi.org/10.1002/hrdq.1193

DeVellis, B. M. (1983). Self-efficacy theory. Patient Education Newsletter, 6(2), 4-6. https://doi.org/10.1007/978-1-44196868-5

Dyson, P. A., Kelly, T., Deakin, T., Duncan, A., Frost, G., Harrison, Z., ... Worth, J. (2011). Diabetes UK evidence-based nutrition guidelines for the prevention and management of diabetes. Diabetic Medicine, 28(11), 1282-1288. https://doi.org/10.1111/j.14645491.2011.03371.x

Gatt, S., \& Sammut, R. (2008). An exploratory study of predictors of self-care behaviour in persons with type 2 diabetes. International Journal of Nursing Studies, 45(10), 1525-1533. https://doi.org/10.1016/j.ijnurstu.2008.02 .006 
Ha, M., Hu, J., Petfrini, M. A., \& McCoy, T. P. (2014). The effects of an educational self-efficacy intervention on osteoporosis prevention and diabetes self-management among adults with type 2 diabetes mellitus. Biological Research for Nursing, 16(4), 357-67. https://doi.org/10.1177/10998004135120 19

Hendrychova, T., Vytrisalova, M., Vlcek, J., Smahelova, A., \& Kubena, A. A. (2013). An analysis of fat-related and fiberrelated behavior in men and women with type 2 diabetes mellitus: Key findings for clinical practice. Patient Preference and Adherence, $\quad 7$, 877-884. https://doi.org/10.2147/PPA.S47497

Herbozo, S., Flynn, P. M., \& Stevens, S. D. (2015). Dietary Adherence , Glycemic Control, and Psychological Factors Associated with Binge Eating Among Indigenous and Non-Indigenous Chileans with Type 2 Diabetes, 792-798. https://doi.org/10.1007/s12529-0159478-y

Inbaraj, L. R., Georg, C. E., Kham, N. L., \& Norman, G. (2016). Prevalence, perceptions and practices associated with non-adherence to diabetes medications in primary care setting: A cross sectional study in urban Bangalore. Asian Journal of Medical Science, 7(6), 106-110. https://doi.org/10.3126/ajms.v7i6.15256

Intercollegiate, S., \& Network, G. (2013). SIGN guidlines for management of diabetes. Management, SIGN(June), Available from www.sign.ac.uk/guidelines/fulltext/. https://doi.org/10.1136/thx.2008.097741

International Diabetes Federation (IDF). (2015). International Diabetes Federation: Diabetes ATLAS Seventh Edition. International Diabetes Federation. https://doi.org/10.1289/image.ehp.v119.i 03

Kaminsky, L. A., \& Dewey, D. (2014). The association between body mass index and physical activity, and body image, self esteem and social support in adolescents with type 1 diabetes. Canadian Journal of Diabetes, 38(4), 244-249.

https://doi.org/10.1016/j.jcjd.2014.04.005

Kementerian Kesehatan RI. (2015). Rencana Strategis Kementerian Kesehatan Tahun 2015-2019. Jakarta: Kementerian Kesehatan RI.

Novack, D. (2013). Self-Efficacy Case Study. Retrieved January 26, 2017, from https://wikispaces.psu.edu/display/PSYC H484/Fall+2013+SelfEfficacy+Case+Study

Pant, S., Ojha, S., Chapagai, M., Tulachan, P., \& Dhungana, S. (2016). Depression and its association with Glycemic Control in Nepalese Adults with Diabetes Mellitus. Journal of Institute of Medicine, 38(1), 89-93.

Papazafiropoulou, A. K., Bakomitrou, F., Trikallinou, A., Ganotopoulou, A., Verras, C., Christofilidis, G., ... Melidonis, A. (2015). DiabetesDependent Quality of Life (ADDQOL) and Affecting Factors in Patients with Diabetes Mellitus Type 2 in Greece. BMC Research Notes, 8(1), 786. https://doi.org/10.1186/s13104-015$1782-8$

Parajuli, J., Saleh, F., Thapa, N., \& Ali, L. (2014). Factors associated with nonadherence to diet and physical activity among nepalese type 2 diabetes patients; a cross sectional study. $B M C$ Research Notes, 7(1), 1-9. https://doi.org/10.1186/1756-0500-7-758

Rosland, A. M., Piette, J. D., Lyles, C. R., Parker, M. M., Moffet, H. H., Adler, N. E., ... Karter, A. J. (2014). Social Support and Lifestyle vs. Medical Diabetes Self-Management in the Diabetes Study of Northern California (DISTANCE). Annals of Behavioral Medicine, 48(3), 438-447. https://doi.org/10.1007/s12160-0149623-x

Rubin, K., Bukowski, W., \& Parker, J. (1998). Peer Interactions, Relationships, and Groups. In Peer Interaction and Relationship: An Historical Overview (pp. 571-645). 
Safita, N., Islam, S. M. S., Chow, C. K., Niessen, L., Lechner, A., Holle, R., \& Laxy, M. (2016). The impact of Type 2 Diabetes on Health Related Quality of Life in Bangladesh: Results from a Matched Study Comparing Treated Cases with Non-Diabetic Controls. Health and Quality of Life Outcomes, 14(1), 129. https://doi.org/10.1186/s12955-0160530-7

Swoboda, C. M., Miller, C. K., \& Wills, C. E. (2017). Patient Education and Counseling Impact of a goal setting and decision support telephone coaching intervention on diet, psychosocial , and decision outcomes among people with type 2 diabetes. Patient Education and Counseling, (2016), 243-250. https://doi.org/10.1016/j.pec.2017.02.007

Tsay, S. (2003). Self-efficacy training for patients with end-stage renal disease.

Viswanathan, M., Golin, C. E., Jones, C. D., Ashok, M., Blalock, S., \& Wines, R. (2012). Medication Adherence Interventions: Comparative Effectiveness. Evidence Report/ Technology Assessment, 208 (AHRQ Publication No. 12-E010), 685.https://doi.org/10.1177/01457217124 64400.Facilitating

Wichit, N., Mnatzaganian, G., Courtney, M., Schulz, P., \& Johnson, M. (2017). Randomized controlled trial of a familyoriented self-management program to improve self-efficacy, glycemic control and quality of life among Thai individuals with Type 2 diabetes. Diabetes Research and Clinical Practice, 123, $37-48$. https://doi.org/10.1016/j.diabres.2016.11. 013

World Health Organization. (2003). Adherence to long-term therapies: Evidence for action. European Journal of Cardiovascular Nursing, 2(4), 323. https://doi.org/10.1016/S14745151(03)00091-4

Wright, K. (2013). Diabetes and the impact on quality of life: a balancing act. $N R C, 15(12)$, 786-790.
Wu, S. ., Courtney, M., Edward, H., McDowell, J., Chang, P. ., BaggetL, M., \& Shortridge, N. (2007). Selfefficacy, outcome expectations and self-care behaviour in people with type 2 diabetes in Taiwan. Journal of Nursing and Health Care of Chronic Illness in Association with Journal of Clinical Nursing, 16(11c), 250-257.

Yin, J., Wong, R., Au, S., Chung, H., Lau, M., Lin, L., ... Chan, J. C. N. (2015). Effects of Providing Peer Support on Diabetes Management in People With Type 2 Diabetes. Annals of Family Medicine, 13(Suppl 1), S42-S49. https://doi.org/10.1370/afm.1853.Hong 